\title{
Securing Public Places: New Zealand's Private Security Sector as a National Security Enabler
}

\author{
Author/s: Nicholas Dynon
}

To cite this article: Dynon, N. (2019). Securing Public Places: New Zealand's Private Security Sector as a National Security Enabler. National Security Journal, 1(1), 75-92. doi:10.36878/nsj201901.75

To link to this article: https://doi.org/10.36878/NSJ201901.75

View CrossRef data: https://search.crossref.org/?q=10.36878\%2FNSJ201901.75\# 


\title{
SECURING PUBLIC PLACES: NEW ZEALAND'S PRIVATE SECURITY SECTOR AS A NATIONAL SECURITY ENABLER
}

\begin{abstract}
Nicholas Dynon ${ }^{1}$
In recent years, national security policy makers globally have grappled with the challenge of addressing the vulnerability of 'public spaces' to terror attack. In the wake of the Christchurch mosque attacks, it's a challenge that has gained sudden urgency in New Zealand. Faced with the numeric impossibility of protecting infinite public spaces within their jurisdictions, several states have enacted strategies to utilise the considerable 'eyes and ears' capability of their private security personnel sectors. While the harnessing of numerically superior private security guard forces presents opportunities for a more linked-up approach to protecting the public, there are also significant barriers. Despite their massive growth in recent decades, private security industries the world over struggle with issues - both real and perceived - around pay and conditions, training, standards and professionalism. With the UK and Australia already having taken steps towards public-private security partnerships, to what extent does New Zealand's private security guarding sector constitute a potential national security force-multiplier?
\end{abstract}

Keywords: New Zealand, national security, counter-terrorism, crowded places, public spaces, private security, police, public-private partnership

In the post-9/11 context, the prevalence of terror attacks perpetrated in sporting stadia, shopping malls, city sidewalks, tourist hotspots and places of worship, has led to an increasing focus by security commentators and policy makers on locations where people congregate - 'crowded places' and 'public spaces' - as the attack venue of choice of terrorists and fixated persons. These notionally public spaces are often - and increasingly -

$1 \quad$ Nicholas Dynon is Chief Editor of New Zealand Security Magazine and Line of Defence Magazine and Group Marketing Manager at Optic Security Group. He holds an M.A. (ANU), an M.IntS Hons (University of Sydney) and a Private Security (CC, PSG, PRG, PI, SC) Certificate of Approval (PSPLA). Contact nxdynon@hotmail.com. The author wishes to thank Mr Gary Morrison and Mr Andrew Thorburn for the insights each provided at interview. Their comments were made in a personal capacity and do not represent those of their respective organisations/employers. 
privately rather than publicly owned. In the shopping malls, retail precincts, entertainment and leisure complexes and al fresco café footpaths of contemporary New Zealand, notions of public and private space have become increasingly complex. From a public or community security perspective, this presents challenges in terms of the proximity of the state to these sites for the purposes of visual surveillance and incident response.

The rise of the private security industry in recent decades is in large part the product of the privatisation of (i) publicly provided security services (policing), and (ii) publicly owned space. The proliferation of 'privately owned public spaces' (POPS) has fuelled growth in private security. On the one hand, the state has pushed responsibilities for the surveillance and policing of these spaces onto the private sector, while on the other hand venue owners see commercial and legal compliance benefits in providing for the security of their patrons/visitors. With so-called public spaces and crowded places now of significance to state counter-terror and national security considerations, private security presents as a potential national security enabler that remains as yet largely untapped.

The proposition that private security may be harnessed purposefully by the state as a national security enabler has been raised - and indeed enacted - in several jurisdictions internationally. In the UK, for example, Project Griffin was established in 2004 to bring together police, fire and ambulance services, private security and government agencies to deter and disrupt terrorist and extremist activity. By 2018, the approach had become part of the United Kingdom's Strategy for Countering Terrorism:

We will seek a more integrated relationship with the private sector both to better protect our economic infrastructure and to scale our ability to tackle terrorism... We will jointly with industry improve security at venues in the UK, gain faster alerts to suspicious purchases and design out vulnerabilities in our infrastructure or in products that terrorists exploit. ${ }^{1}$

In Australia, a Project Griffin spin-off was established in 2007 by Victoria Police Counter-Terrorism and Emergency Management Division to train security staff on identifying potential threats to client premises; and in 2017, Australia's Strategy for Protecting Crowded Places from Terrorism identified a key role for private security consultants in advising owners and operators of crowded places. Against this background, the Australian Strategic Policy Institute (ASPI) published a Special Report in October 2018 titled Safety in numbers: Australia's private security guard force and counterterrorism. Authored by Bergin, Williams and Dixon, the report explores the feasibility of the private security personnel industry playing a role in Australia's counter-terror efforts. ${ }^{2}$ The challenges and opportunities identified in that report, as this paper will discuss, share many parallels with the New Zealand context. 
Examining the current state of public-private cooperation in security matters in New Zealand, this paper explores the potential for the harnessing of the non-government security sector as a counter-terror force multiplier.

\section{A Public-Private Security Continuum}

\section{National security}

According to New Zealand's National Security System Handbook, "National security is the condition which permits the citizens of a state to go about their daily business confidently free from fear and able to make the most of opportunities to advance their way of life. It encompasses the preparedness, protection and preservation of people, and of property and information, both tangible and intangible."' Following from this definition, both the Handbook and the New Zealand Defence White Paper 2016 list 'seven overarching national security objectives', from preserving sovereignty and territorial integrity, to protecting lines of communication, to public order and protecting the safety of citizens and communities. ${ }^{4}$

The wide-ranging definition of national security employed by both documents flows from the 2001 Cabinet decision that New Zealand take an "all hazards - all risks" approach to national security. ${ }^{5}$ According to the 2016 Controller and Auditor-General report Governance of the National Security System, this approach "means that the [National Security] System includes all risks to national security, whether internal or external, human or natural". ${ }^{6}$ Incorporating elements of both 'national security', which is traditionally seen as 'outward facing' and domestically-focused 'homeland security', this all-embracing notion of national security can also be understood in terms of the concept of 'human security', which shifts security away from its traditional focus on the state to a focus on people.

New Zealand's capacity to deal with the full range of national security challenges, acknowledges the National Security System Handbook, requires a system "able to leverage partnerships between government agencies, local government, private companies, and individuals." Indeed, the 2012 Formal Review of the New Zealand Police by Treasury, State Services Commission (SSC) and the Department of Prime Minister and Cabinet (DPMC) acknowledges the role of private security firms in "providing a first response capability and contributing to the safety of New Zealand communities." Such recognition, however, is largely platitudinal. In reality, the private security industry is given no place in the National Security System, and industry peak bodies, such as the New Zealand Security Association (NZSA), are not engaged by police or relevant government agencies on matters of security planning despite efforts to achieve cut-through. The lack of a published national security or counter-terrorism strategy, as noted by Azizian and Rothery ${ }^{8}$ - let alone one that acknowledges any role for the private security sector 
- isn't helpful. In the New Zealand context, although the state in general and the police in particular have a history of engaging private security providers, this has tended to be in relation to lower-value, routine activities only. International experience suggests that New Zealand lags behind other comparable jurisdictions, such as Sweden, the UK and Australia, in fostering public-private cooperation in the security sector.

\section{Private versus public security sector}

This paper focuses on the activities of three of the eight classes of 'persons' (individuals and companies) who are required by Section 23 of the Private Security Personnel and Private Investigators Act 2010 (PSPPI Act) to hold a private security licence or certificate of approval (CoA); specifically property guards, personal guards, and crowd controllers. ${ }^{9}$ These persons are described as operating within the 'personnel' sector of the broader security industry, although definitions of this sector vary considerably, and questions among researchers over which occupations constitute it remain unresolved. Definitions invariably include roles such as door staff, bouncers and bar security, stewards, concierge staff, gatehouse staff, close personal protection officers, bodyguards, static guards, watchpersons, covert and overt loss prevention officers, cash-in-transit officers, behaviour detection officers, patrol officers, alarm responders, and control room and monitoring centre operators.

Although the private security industry tends to be defined in terms of what distinguishes it from providers of public security services, such as the police, the dichotomies between 'public' and 'private' police and policing are widely seen as increasingly unclear. Traditional policing activities are now conducted not just by 'the police' but by a host of private and non-government operatives who use a range of empowerment tools and resources at their disposal, including criminal law, by-laws, and non-legal instruments such as conditions of entry. Terms such as 'pluralisation', 'greying' or 'fragmentation' of policing, 'para-' or 'hybrid' policing, 'continuum of activity', 'security quilt' and 'mixed economy of protection' are used to describe this dynamic. ${ }^{10}$ Such nomenclature is reflected in the aforementioned 2012 Formal Review of the New Zealand Police:

An opportunity for improving policing outcomes, and managing the growing demand for Police assistance, is for Police to find ways to work more effectively in a pluralistic policing environment. In many communities Police is one of a number of 'policing' agencies.

The growing role of the private security sector globally in law enforcement and related activities - including in New Zealand - is widely acknowledged. ${ }^{11}$ Indeed, according to Button, there "are very few activities in the broader criminal justice system and policing that private security is not undertaking or is not capable of doing." ${ }^{12}$ Stenning and Shearing list three often-cited explanations for this growth in private security: (i) the privatisation of publicly provided services and 'responsibilisation' strategies encouraged 
by neo-liberal governance agendas; (ii) changes in the nature of property ownership, in particular the development of privately owned public spaces; and (iii) filling gaps in public policing services in times of fiscal cuts (although this could be classified as a subset of 'responsibilisation').

\section{Privatisation of publicly provided services}

Private security is widely seen as the market's answer to the retreat of the state from certain public policing functions, yet this is an area contested among researchers. The rise of private security is seen by some as a reaction to the perceived institutional failure of public security. Pavarini, for example, notes that public efforts to provide safeguards against criminality "are perceived as being unable to meet the social demand for security." ${ }^{13}$ This, he suggests, may be more the result of subjective perceptions of insecurity as opposed to an increase in levels of actual insecurity. Others, such as Cleghorn et al, point to rising crime rate statistics as a driving force for the industry's growth. ${ }^{14} \mathrm{~A}$ range of perspectives are summed up by Zedner:

Security is bought because people can afford to do so; because they have so internalised the 'responsibilisation' strategies of governments they consider it their duty to do so; because it adds value to their property; reduces their insurance premiums; or prevents them from falling behind their more security conscious neighbours..$^{15}$

In the UK, promotion by the state of private sector involvement in criminal justice through legislative change, outsourcing and the fostering of partnerships has bolstered the legitimacy of the private security industry and resulted in a greater public security role for private security providers. Project Griffin is perhaps the best-known example of this. Garland describes this trend as a strategy of 'responsibilisation' in which the state seeks to promote action by non-state organisations in a 'shared' approach to crime control. ${ }^{16}$

According to Cleghorn et al, up until the 1980s "most New Zealanders believed that their personal protection and the protection of their property was guaranteed by the Government through its law enforcement agencies."17 Decades of privatisation and deregulation following 1974's Private Investigators and Security Guards Act have to some extent diluted the state's security monopoly into a more complex dominance supported by a network of non-government suppliers and stakeholders. Bradley notes that between 1976 and 2012 the country's licensed security industry grew by over 1,000\%, while over the same period, the police grew by a relatively modest $117 \% .{ }^{18}$ Such figures support the notion shared by NZSA CEO Gary Morrison and ASIS International New Zealand Chapter (ASIS NZ) ${ }^{19}$ Chair Andrew Thorburn that "the driver [for industry growth] has been where private policing is taking over from what is no longer public policing". ${ }^{20}$ According to Morrison, the growth in mobile security patrols, for example, stems from 
police no longer providing alarm response services. In addition, private security has taken over the police functions of security of cash and valuables in transit, and the securing of public events. Private security personnel also undertake first-responder, public safety and crime prevention roles in the course of carrying out their work on client sites, such as conducting visual surveillance of the site (via either patrolling or overt CCTV monitoring), assisting in the recovery of stolen vehicles (including via automatic number plate recognition surveillance integrated with police systems), assisting in the apprehension of persons of interest, ${ }^{21}$ handing-over when responding to incidents requiring police presence, and providing witness statements in court.

Morrison also notes that significant growth in the personnel sector is the result of government authorities (such as city and district councils) outsourcing compliance-type functions, such as noise, smoke and animal control, freedom camper by-law enforcement, parking enforcement, permit issuance, speed enforcement, and security functions that were hitherto provided in-house. Private security providers deliver security guarding, patrol and alarm response services to government buildings, military bases, hospitals, educational institutions, ports and critical infrastructure. The industry also provides security for specific central government agency activities, such as Ministry for Primary Industries (MPI) 1080 poison drops, Department of Corrections prison escort and court custodial services, ${ }^{22}$ and the electronic monitoring of thousands of offenders serving community-based sentences and defendants on electronic bail.

\section{Privatisation of public space}

Heralded as "New Zealand's first American-styled shopping centre", Lynnmall opened in West Auckland on 30 October 1963. Since the 1960s, notes Walrond, "there has been a trend toward public life taking place on private property, ${ }^{23}$ with recent decades witnessing what has been referred to as 'spatial privatisation' or the 'mass privatisation' or 'territorialisation' of public space, including the privatisation of public space ownership and management. ${ }^{24}$ Shopping malls, entertainment and lifestyle complexes, sporting and leisure centres and transport hubs are described as examples of 'privately owned public spaces' (POPS), 'augmented', 'semi-' or 'pseudo public space. ${ }^{25}$ According to Wakefield, the expansion of mass private property environments in the UK and elsewhere is identified by several researchers as a key factor in the growth of private security, "as property owners have recognised the commercial benefits of employing their own security forces." ${ }^{26}$ Rice notes, for example, that shoppers "often say they feel safer [in malls] than on traditional shopping streets" due to being sheltered from the weather and protected by private security guards. ${ }^{27}$ University of Auckland researchers Alison Greenaway et al., note the increasing privatisation of public space management in Auckland through the use of private security guards "and the 'cleaning up' of public spaces".28

Publics in the UK, Australia and New Zealand are spending increasing amounts of time in POPS like shopping centres to the extent that these sites have become the subject 
of legal and philosophical debate over accessibility, surveillance and conditions of entry. ${ }^{29} \mathrm{~A}$ number of researchers, including Giddens and Wakefield, note that designers and managers of POPS foster a sense of 'ontological security' among the users of their spaces, using safety and security as a key element in the attraction of patronage and, ultimately, the achievement of commercial success. Private security officers in these locations often enforce rules and behavioural conditions set by premise owners that are more restrictive than one might be subject to in a public space owned by the state.

Spatial privatisation is not limited to single buildings, with multi-building 'precincts' and in some cases multiple city blocks - and the lanes and thoroughfares that crisscross them - in private hands. Minton, for example, notes "the rise of individual landlords owning and managing entire city centre schemes." ${ }^{30}$ This can be seen in massive multi-block developments, such as London's Canary Wharf, but also in New Zealand in developments such as downtown Auckland's privately-owned Britomart precinct. Importantly, and as critics of spatial privatisation note, given that POPS have the look and feel of public land, a pedestrian may not have any awareness of where the public land ends and privately-owned space begins. ${ }^{31}$ According to Auckland CBD business association Heart of the City:

We've seen a laneway renaissance in downtown Auckland over the last few years, with property owners turning under-used ground floors and carparks into vibrant areas for bars, cafes, and most importantly, people...

One thing that Britomart and the Fort Street area have in common is the blurring between public and private spaces, with privately owned laneways that look like public streets and even have the same style of paving stones carrying through from the street outside. ${ }^{32}$

In shared-street contexts, there is also the dynamic of what Kayden terms 'café creep', 'brasserie bulge' or 'trattoria trickle' - where publicly-owned space is encroached upon by private shop operators. Occuring on sidewalks, pedestrian laneways and pedestrianised malls that are typically highly vulnerable to terror and fixated person attack, these spaces further complicate the already complex relationship between public and private spaces and the management of the security and safety of these. ${ }^{33}$

\section{Security Guards: A counter-terror force-multiplier?}

\section{Superior numbers}

The aforementioned growth in the private security industry is best illustrated by the fact that in recent decades in increases in private security personnel numbers have outstripped that of police personnel numbers. As Button notes, research confirms that this expansion has led to the outnumbering of police officers by private security personnel 
in most industrialised countries, ${ }^{34}$ with the average security officer-to-police officer ratio across the UK, Australia and New Zealand averaging around 2:1.

In the UK it is speculated that private security outnumbers police by a ratio as high as two-to-one, equating to a possible 300,000 employees. ${ }^{35}$ By comparison, in March 2018, there were 125,651 police officers in England and Wales (in 1979 there were around 110,000). ${ }^{36}$ Of Australia, Sarre and Prenzler note that "the security industry is growing at a faster rate than both the increasing growth in police numbers and the Australian population." Consistent with the UK, they suggest that the industry personnel may outnumber police by two-to-one. ${ }^{37}$ The authors of the ASPI Special Report estimate the total number of guard and crowd control license holders to number more than 120,000 (from a total of 190,000 licenses given that many individuals hold licenses across multiple classes). By comparison, they note that Australia possesses approximately 56,750 police and 58,060 permanent defence force personnel.

In 1996, New Zealand's security industry was made up of 968 license-holding businesses (a 53 percent increase on 1986), 5,380 CoA holders (employees), and an estimated 1,600 illegal operators..$^{38}$ According to Bradley, as of December 2016, 24,294 persons were holders of an individual license or CoA (each one covering any number of the eight licensing categories) - an over four-fold increase on the number 20 years previously. By comparison, as of 30 June 2016, the New Zealand Police numbered 12,034 (9,004 sworn and 3,013 unsworn) members, and as of June 2017 the New Zealand Defence Force totalled 11,900 active personnel.

In the case of Australia, the ASPI Special Report claims that the private security sector has - in some areas - resources and capabilities beyond those of government. "It has the bulk of personnel responsible for guarding assets and events and for providing an immediate response to an incident." ${ }^{39}$ Both in Australia and New Zealand, the sector also has a comparative ability to 'surge' in response to unexpected demand. The larger security guarding and patrol providers, for example, maintain pools of temporary staff and networks of trusted sub-contractors for work that exceeds their permanent in-house capacity or geographic footprint.

\section{On the spot in public spaces}

In stadium-based terrorist attacks in Paris in 2015 and Manchester in 2017, notes the ASPI Special Report, the interventions of security guards in denying entry to would-be bombers resulted in there being fewer fatalities than might have otherwise have been the case. In November 2018, when a deranged individual took to Melbourne's Bourke Street with a gas cylinder-laden ute, a large knife, and an apparent intent to cause harm, three members of the public were randomly stabbed, including an on-duty SECUREcorp security guard. It all happened so fast that the guard had no opportunity to defend himself against the initial blow. Had things been different and hed had time to 
observe, report and react, he would have effectively been the first responder. Victoria Police officers arrived at the scene minutes later.

Sarre and Prenzler make the quite reasonable assertion that "citizens are far more likely to encounter private security personnel (and their security devices) than police officers in their day to day activities."40 Collectively, private security officers possesses a relative 'surveillance ubiquity' due to their number, and also due to the fact that they are deployed to the very type of publicly and privately owned 'public places' that have become the venues of recent weapons attacks and acts of terror. In the event of an attack they may be already at the scene, or otherwise positioned closer to it than the nearest police officer. They also cost less than state-provided security and law enforcement.

While an attacker's choice of weapon has been shown in recent examples to be dependent on availability and opportunity, such as automatic assault rifles in Christchurch, hostile vehicle in Nice, knives in Melbourne and London, and bombs in Paris, London and elsewhere, the one constant in these attacks is the choice of a public space as venue. From a counter-terrorism preparedness perspective, it is these very spaces and their owners and operators that have become the focus of government strategies such as the Australia-New Zealand Counter-Terrorism Committee's (ANZCTC) Australia's Strategy for Protecting Crowded Places from Terrorism.

On any given day, private security personnel provide security to any number of malls, office buildings, transport hubs, government offices, defence facilities and critical infrastructure sites. The point is, private security staff could be the 'eyes and ears' before any attack and the first response after any security-related incident, and they are more likely than their defence and law enforcement colleagues to be 'on the spot'. Superior personnel numbers and ubiquity in public spaces are characteristics that support the proposition that the private security industry is well-placed to serve as a potential national security enabler. But it's a proposition that has its problems. Although numerically strong, the licensed security guard population is widely considered to be low skilled, and their generally low wages reinforce this. Although regulated, barriers to entry and compliance mechanisms reflect a regulatory light touch, and the industry suffers from a poor reputation among the public and among government security and law enforcement partners. All together these present barriers limiting the potential of the industry to play a meaningful and formalised role in New Zealand's national security.

\section{Low skilled, minimum wage}

Within the OECD, security guarding is widely considered a low-skill, low-wage occupation. "National security planners and police generally view the guarding sector as low-paid, entry-level employment that anyone can do with minimal training," state the authors of the ASPI Special Report. ${ }^{41}$ The NZSA's Gary Morrison explains that security providers in New Zealand have tended to provide "low-level functions that are 
perceived as not requiring a high skills base or level of training." ${ }^{42}$ The security industry is not widely viewed as a career option of choice, and ultimately neither does it tend to be regarded an actual career. According to Couper and O'Donnell, private security is "not seen as a profession in New Zealand at all despite the fact that it is in many other jurisdictions." ${ }^{43}$ ASIS NZ's Andrew Thorburn argues that this needs to change. "We need to show people that there is a pathway from being a security telephony operator to a static officer to a mobile patrol officer and to a supervisor and manager, and perhaps recruitment to the police or military." ${ }^{44}$

Under the PSPPI Act, all companies and workers in the security industry must hold appropriate licences as evidence of meeting fit and proper requirements, but those requirements are widely seen as constituting a very low barrier to entry. Couper and O'Donnell comment that the security licensing regime "brought us nothing apart from a 40-hour requirement for mandatory training for door controllers and security officers" and no other requirement for training. ${ }^{45}$ These 40 hours equate to three NZQA unit standards which, they point out, represent a small proportion of the units that constitute the National Certificate in Security (Level 2)] Lawton concurs that the mandatory training requirement is insufficient, covering only basic security law and conflict resolution, and should be viewed as a minimum. Lawton makes the comparison that mandatory training in Australia covers the majority of the content of the National Certificate in Security (Level 2)). ${ }^{46}$ Mandatory training, according to Morrison, provides security personnel "with the bare minimum to give them the ability to go and start working safely with a minimum degree of knowledge that would be built up from there." Thorburn believes that mandatory licensing and mandatory training has not had the positive impact it was intended to have, nor has it resulted in more capable security officers, nor mitigated the risk of injury to them.

According to Morrison, only $15 \%$ of security guards go on to NZQA qualifications beyond mandatory training (i.e. National Certificate in Security (Level 2) or above). The $\mathrm{E}$ tu union, which represents workers in the security sector, has pushed for some time for a collective agreement to improve wages and include free Level 2 training in the first year of employment, but its overtures to providers have fallen flat. Some providers have looked to pass the 'living wage' to their employees and to offer Level 2 as part of an enhanced induction training programme, but in many cases such moves are client-specific (i.e. passed onto only those employees working within certain contracts that require it) rather than across the board. Couper and O'Donnell also believe that appropriate training is lacking beyond the entry level. "The only real training that's going on is mandatory training and little tiny pockets of other training, such as the CPP and PSP ASIS accreditations." ${ }^{37}$ While a National Diploma in Security (Level 6) exists, there is virtually no up-take of this qualification.

The problem, as described by the NZQA, is that the industry is "a competitive and price-sensitive environment with a high staff turnover" ${ }^{\prime 4}$ of mainly part-timers, often 
on minimum wages and working long hours. ${ }^{49}$ This is echoed by Moriarty, who characterises security in New Zealand as "a low margin business with no appetite for training beyond the basics... dumbed down through the process of having security companies compete over lower rates of pay per hour for contracts". According to Thorburn, continuing high rates of staff attrition:

are not a very good indicator that we're doing things right... As long as it's a minimum wage industry, the perception is always going to be that it is low entry, low skill, and attracts a low IQ individual. ${ }^{50}$

\section{Public and police perception}

Negative perceptions of the professionalism of private security officers are held by law enforcement agencies on both sides of the Tasman. According to the ASPI Special Report, national security planners and police "generally view the guarding sector as lowpaid, entry-level employment that anyone can do with minimal training," and because of this they have a perception that private security officers "aren't valuable". ${ }^{51}$ One security manager interviewed for the ASPI Special Report goes so far as stating that the police "treat us like idiots." Similarly, the NZSA's Morrison observes that a dominant perception within New Zealand Police of private security officers is that they are "reasonably low skilled, there to provide a certain function and probably not beyond that." 52

Such negative perceptions are not helped by the fallout from the Southern Response controversy and resulting Report of the State Services Commission (SSC) Inquiry into the Use of External Security Consultants by Government Agencies, published 18 December 2018. Addressing public concern over the use of external consultants by government agencies to undertake intrusive activities, the report focused on government use of Thompson and Clark Investigations Ltd to conduct surveillance of individual insurance claimants. Although the report noted the "wide range of security camera and security guard providers that are properly engaged by government agencies," the controversy nevertheless prompted many agencies to review their interactions with private security providers. ${ }^{53}$

Thirteen days prior to the release of the SSC inquiry report, New Zealand Police published the findings of an internal investigation conducted in light of public concerns that the SSC's inquiry had not included Police due to its statutory independence. The report, Engagement of External Security Consultants, found overall Police engagement with external security consultants to be consistent with Police values and the New Zealand Police Code of Conduct, albeit with isolated exceptions. Among its recommendations, however, were that policy and training in the areas of managing conflicts of interest and maintaining professional distance be "amended to highlight the particular risks of interacting with external security consultants," and that membership of government multi-agency groups formed to coordinate government responses to particular issues 
be restricted to government agencies only. Such measures risk creating a climate that places the security industry at even greater arm's length from government agencies than was previously the case. ${ }^{54}$

In terms of perception among the New Zealand public, the Police, along with the New Zealand Defence Force (NZDF), New Zealand Customs and other government security and law enforcement agencies, enjoy positive reputations. This reflects international benchmarking, such as Transparency International's 2019 Corruption Perceptions Index, which ranked New Zealand's public sector the second most least corrupt globally. ${ }^{55} \mathrm{Ac}-$ cording to the New Zealand Defence Force Annual Report 2014, the results of an independent public opinion poll conducted on the NZDF showed that "New Zealanders continue to be favourable towards the NZDF" ${ }^{56}$ In the Ministry of Justice's 2014 New Zealand Crime \& Safety Survey, 73\% of respondents rated the Police as excellent/good, and $19 \%$ as fair. In the Police sponsored 2017-18 Citizens' Satisfaction Survey, 68\% of 9,000 respondents surveyed reported "full/quite a lot of trust and confidence" in Police, and $88 \%$ said Police staff were competent. ${ }^{57}$

In contrast, the involvement of the private security industry in providing services and solutions to law enforcement agencies and to the broader economy is not widely understood or highly regarded. As a low-skilled, poorly paid, lightly-regulated and increasingly transient occupation, security guarding is generally perceived by society in unattractive terms. Public perceptions of the industry are disproportionately informed by negative stereotypes around its more public-facing roles: the ubiquitous static security guard, crowd controller and bar security staff. According to Pepper, if security providers in New Zealand aren't investing in these staff "and ensuring they're properly trained for the job they're doing, the public sees that." ${ }^{58}$ ASIS NZ's Thorburn notes that the archetypal security officer posted outside a financial institution:

... will quite often be of retirement age, will not even engage with people coming in and out of the client's property, and at times seem to be asleep on their feet. That perception unfortunately is what gets carried across to other disciplines, such as patrol officers, alarm response officers, static officers for corporate/commercial buildings. ${ }^{59}$

With guarding constituting the 'public face' of the industry, there is also a lack of public awareness of the depth and breadth of the industry beyond guarding services (such as security consulting, video and electronic surveillance and access control, systems integration, monitoring centres, GPS-based and autonomous security solutions, analytics, investigations and enterprise security risk management services).

Perceptions of private security are also skewed by media sensationalism around such issues as the use of unreasonable force by bar security staff and over-zealous security management of crowd behaviour at sporting events. In her Australia-focussed research, 
Hayes-Jonkers identifies rhetorical and discursive strategies used in news reports to undermine bouncers' credibility and portray the security industry as staffed with violent, undertrained, criminal personnel. "Under- and over-statements, metaphors, and metonymic concepts, together with lexical choice, styles and structures," states HayesJonkers, "are used freely by the news media to vilify, discriminate against and discredit bouncers. ${ }^{60}$ In research on press depictions of Sydney's night-time economy, Wadds argues that print media reflects public ambivalence and insecurity by representing the private security industry as unruly and violent, and with links to criminality. ${ }^{61}$

\section{Light touch regulation}

The authors of the ASPI Special Report, noting the training, standards and perception challenges facing Australia's security industry, suggest that a nationally consistent vetting, training and licensing system would "greatly enhance the ability of licensed security officers to identify, prevent and respond to critical incidents and hostile threats, such as terrorism." ${ }^{2} 2$ They recommend the establishment of a federal Security Industry Authority (SIA) responsible to Australia's Minister for Home Affairs. Its functions would include: (i) the integration of the private security manpower sector into Australia's counter-terrorism strategy; (ii) 'fit and proper person' definition and assessment; (iii) training development and monitoring of delivery standards; (iv) external confirmation of testing and competencies; and (v) the development and promulgation of additional $\mathrm{CT}$ awareness and training information.

Compared to the UK, US and Australia, New Zealand's private security industry is lightly regulated. The existing regulatory regime provided by the PSPPI Act, and which includes the Private Security Personnel Licensing Authority (PSPLA) within the Ministry of Justice and the Complaints, Investigation and Prosecution Unit (CIPU) within the Department of Internal Affairs, is widely regarded as a 'light touch' model focused on vetting and administration as opposed to enforcement and best practice. This regime, states Bradley, "leaves the New Zealand public with a state centred regulatory system that is insufficiently comprehensive to achieve marked improvements." ${ }^{33}$ Morrison observes, however, that recent prosecutions reflect the move to a more punitive approach. He notes the recent conviction and fining of Sean Micheals for operating the businesses Corporate Group International Limited, Corporate Protection and Security International Limited and HD Security Services Limited without a licence. "Security services are often in positions of authority and having unlicensed cowboys in the industry puts the public at real risk," Marty Greentree of the Department of Internal Affairs told media in relation to this case. "If people break the law, we will catch them." ${ }^{64}$ Thorburn argues that in order for there to be sufficient trust of the security industry by those interacting with it, there needs to be a greater focus by the PSPLA on prosecutions "such as what happens with the SIA in the UK and more recently within Australia." ${ }^{65}$ 
In the absence of political appetite to legislatively tighten the licensing regime, government procurement is emerging in New Zealand as a non-legislative model of standards setting. It is not uncommon, for example, for Requests for Tenders/Proposals to require tenderers to hold NZSA membership, which provides assurance that at least the provider is aware of and 'signed up to' to the NZSA Code of Professional and Ethical Conduct. But this falls short of requiring providers to hold the higher 'accredited member' status, which is an elective form of NZSA membership that subjects a provider to auditing against sector-specific Codes of Practice.$^{66}$ Morrison notes that in the context of the redrafting of the Government Procurement Rules (4th ed.), recent engagement between the NZSA and MBIE has focused on improving employment practices in the industry as opposed to professional standards. This has led to talk of implementing an 'approved supplier list' requiring a supplier to be an accredited member of the NZSA and meet additional employment conditions-related evidentiary requirements. Such an approach would bear similarities to the Approved Contractor Scheme referred to by Bradley, which is described as a 'meta-governance' model that could supplement and reinforce the existing regulatory foundation provided by the PSPPI Act "while compensating for some of its weaknesses".

According to Morrison, however, although MBIE's employment conditions focus is a positive step, it also represents a missed opportunity. In particular, an NZSA recommendation to MBIE that the Government Protective Security Requirements (PSR) be highlighted as a component of the Government's procurement of security services has failed to receive traction. The role of the state in procurement-led approaches to standards setting within the industry is perhaps further undermined by the fact that many of the providers listed on relevant government procurement panels (i.e. the ICT Security and Related Services Panel and Protective Security Services Sub-Panel) are not holders of security licenses. "You have IT security consultants advising government who are not licensed," states Thorburn. "They are not going through the same criteria that the law was intended for. Government must lead by example." In summary, there exists significant room for the state to take a more proactive role in raising basic standards - by either a legislative or procurement-led approach.

\section{Conclusion}

New Zealand's 20,000-strong private security personnel sector is a potential national security enabler that remains largely untapped. The sector contributes to the security of New Zealanders in the various roles it performs for public and private sector clients, and it does so successfully despite issues around pay, skills and standards. Security guards are more voluminous and ubiquitous than beat police and they effect surveillance and public order functions in most of the places where members of the public choose to congregate. Yet the private security industry does not feature in the National Security System, it is absent from national security planning, and there exists not a single insti- 
tutionalised relationship between the industry and any of the government agencies one might assume it would have a relationship with.

Relative to comparable jurisdictions internationally, public-private cooperation in security in New Zealand is hampered by a continuing assumption by the state of its own absolute preponderance in security affairs. Ironically, this assumption is at odds with the dynamic of government-driven responsibilisation that has fuelled the industry's spectacular growth. Exactly how the state might more meaningfully engage with the sector, and how it might harness the surveillance, reporting, incident response and security management roles of the private security industry as a 'complementary capability' in the national interest are questions that naturally lead from the above discussion. They are - or ought to be - inevitable questions, the answers to which have the potential to make New Zealand's public places - and the people who frequent them - safer.

1 CONTEST: The United Kingdom's Strategy for Countering Terrorism, HM Government, June 2018. Available at https://www.gov.uk/government/publications/counter-terrorism-strategy-contest-2018 (accessed 07 September 2019).

2 Anthony Bergin, Donald Williams and Christopher Dixon, Safety in numbers: Australia's private security guard force and counterterrorism, ASPI Special Report, October 2018. Available at https://www. aspi.org.au/report/safety-numbers (accessed 07 September 2019).

3 National Security System Handbook, Department of Prime Minister and Cabinet, New Zealand Government, 01 August 2016. p.7. Available at https://dpmc.govt.nz/publications/national-security-system-handbook-html (accessed 07 September 2019).

4 New Zealand Defence White Paper 2016, Ministry of Defence, New Zealand Government, June 2016. p.17. Available at https://www.defence.govt.nz/assets/Uploads/daac08133a/defence-white-paper-2016.pdf (accessed 07 September 2019).

5 POL Min (01) 33/18.

6 Governance of the National Security System, Office of the Auditor-General, New Zealand Government, November 2016. Available at https://www.oag.govt.nz/2016/national-security/part2.htm (accessed 07 September 2019).

7 The bureaucratic construct 'homeland security' has varied over time, and varies between jurisdictions. Paul Rosenzweig: "the impetus for forming the Department of Homeland Security (and conceptualizing the idea of defending the homeland) lies in a clear national security defeat for the nation in the 9/11 attacks (Paul Rosenzweig, "Is Homeland Security A Subset Of National Security?", Lawfare blog, 06 April 2017, Available at https://www.lawfareblog.com/homeland-security-subset-national-security (last accessed 07 September 2019). "the national effort to ensure a homeland that is safe, secure, and resilient against terrorism and other hazards where American interests, aspirations, and ways of life can thrive to the national effort to prevent terrorist attacks within the United States, reduce the vulnerability of the U.S. to terrorism, and minimize the damage from attacks that do occur" ("Defining Homeland Security: Analysis and Congressional Considerations", 08 January 2013. p.8. www.fas.org).

8 See Rouben Azizian (interview), "A comprehensive approach to national security and a more assertive New Zealand in regional security?", Line of Defence Magazine, Autumn 2017. Available at http:// www.defsecmedia.co.nz/international-security/line-defence-march-2017-rouben-azizian/ (last accessed 07 September 2019). See also Chris Rothery. (2019) “Time for a National Security Strategy”, National Security Journal, Massey University Centre for Defence and Security Studies, October 2019.

9 Private Security Personnel and Private Investigators Act 2010, Part 2 - Licences and certificates; Subpart 1 -Licences - Who must be licensed. Note: under the Act, no Police employee or Crown employee is required to hold a licence. Classes of people requiring licenses under the Act include: private investigators, security technicians, security consultants, confidential document destruction agents, 
repossession agents, property guards, personal guards, and crowd controllers. Available at http://www. legislation.govt.nz/act/public/2010/0115/55.0/DLM1594525.html (accessed 07 September 2019).

10 Rick Sarre, "Private Police: The future of policing and the broader regulatory framework", Australian Institute of Criminology, 2002.

11 Mark Button, "Community safety and the private security sector", in Peter Squires (ed.), Community Safety: Critical Perspectives on Policy and Practice, (Bristol, The Policy Press, 2006). p.125.

12 See Brian Forst and Peter K. Manning, The Privatization of Policing: Two Views, 1999, Georgetown University Press. See also Mark Button, op cit. p.125.

13 Lucia Zedner, "The concept of security: an agenda for comparative analysis", Legal Studies, 23, 2003. Available at https://www.axelarnbak.nl/wp-content/uploads/2014/03/Zedner-2003-The-concept-of-security-an-agenda-for-comparative-analysis.pdf (last accessed 07 September 2019).

14 Sharron Cleghorn, et al., Analysis of the New Zealand Security Industry, Massey University student paper, August 1997. This report notes growth in crime of 4.46\% annually between 1972 and 1997.

15 Zedner, loc cit. p.160.

16 Alison Wakefield, "The Public Surveillance Functions of Private Security", in David Wood (ed), Surveillance \& Society, Vol 2 No 4 (2004): People Watching People. p.534. Available at https://panoptykon.org/sites/default/files/3362-5673-1-pb.pdf (accessed 07 September 2019).

17 Cleghorn, et al., op cit. p.8.

18 Trevor Bradley, "Governing private security in New Zealand.", Australian \& New Zealand Journal of Criminology, Vol. 49(2) 159-178, 2016.

19 American Society of Industrial Security is abbreviated ASIS and is known by the brand ASIS International.

20 Interview of ASIS NZ Chair Andrew Thorburn, Auckland, 28 August 2019.

21 For example, where a private security officer comes across a person of interest in the course of their duties and provides information about their whereabouts to police.

22 The New Zealand Court Security Act 1999 allows the chief executive to employ or contract for court security officers.

23 Carl Walrond, "Security and personal safety", Te Ara - the Encyclopedia of New Zealand, 05 May 2011 (updated 01 August 2017). Available at https://teara.govt.nz/mi/security-and-personal-safety/print (accessed 07 September 2019).

24 Manfredo Manfredini, et al., "Give Us Space! Augmented public space geographies in the changing public/private relationships", The Journal of Public Space, 2018, Vol. 3 n. 1. Available at https://www. journalpublicspace.org/index.php/jps/article/view/327 (accessed 07 September 2019).

25 Privatisation of Public Space, CBRE. Available at https://www.cbre.co.uk/research-and-reports/ our-cities/privatisation-of-public-space (accessed 07 September 2019).

26 Wakefield, loc cit. p.532.

27 Geoffrey Rice, "City public spaces", Te Ara - the Encyclopedia of New Zealand, 11 March 2010. http://www.TeAra.govt.nz/en/city-public-spaces/print (accessed 07 September 2019).

28 Alison Greenaway, et al., Young People, Alcohol and Safer Public Spaces, Alcohol \& Public Health Research Unit Whariki Research Group, University of Auckland, June 2002. Available at http://aphru. ac.nz/projects/publicSpaces.pdf (accessed 07 September 2019).

29 Button, loc cit. p.130.

30 "The privatisation of public space", Design Build Network, 23 April 2017. Available at https://www. designbuild-network.com/features/featurethe-privatisation-of-public-space-5776190/ (last accessed 07 September 2019).

31 Jack Shenker, "Revealed: the insidious creep of pseudo-public space in London", The Guardian, 24 July 2017. Available at https://www.theguardian.com/cities/2017/jul/24/revealed-pseudo-public-space-pops-london-investigation-map (accessed 07 September 2019).

32 "Snickel Lane: a new addition to Auckland's downtown laneway neighbourhood", Heart of the City, Auckland, 20 February 2018, Available at https://www.hotcity.co.nz/latest-updates/snickel-lane-new-addition-aucklands-downtown-laneway-neighbourhood (accessed 07 September 2019).

33 Jerold Kayden (interview), "How Privatization Impacts Public Spaces And Infrastructure", WBUR website, 11 May 2017. Available at https://www.wbur.org/hereandnow/2017/05/11/privately-owned-public-space (accessed 07 September 2019). 
34 Button, loc cit. p.125.

35 See Jones, Trevor and Newburn, Tim (1998) Private security and public policing. Clarendon studies in criminology. Clarendon Press, Oxford. See also Bruce George and Mark Button (2000), Private Security, Palgrave Macmillan, 2000.

36 Grahame Allen and Yago Zayed, Police Service Strength, 16 October 2018, House of Commons Library, Briefing Paper 00634. Available at http://researchbriefings.parliament.uk/ResearchBriefing/ Summary/SN00634\#fullreport (accessed 07 September 2019).

37 Rick Sarre and Tim Prenzler, "Private Security and Public Interest: Exploring Private Security Trends and Directions for Reform in the New Era of Plural Policing", Australian Research Council Report, April 2011, Available at https://www.asial.com.au/documents/item/12

38 Cleghorn, et al., op cit.

39 Bergin, et al., op cit. p.8.

40 Sarre and Prenzler, loc cit.

41 Bergin, et al., op cit.

42 Interview of Gary Morrison, NZSA CEO, Auckland, 14 June 2019.

43 Bruce Couper and Charlie O'Donnell (interview), "INTERVIEW: State of the industry with RISQ New Zealand", New Zealand Security Magazine, February-March 2018. Available at http://www.defsecmedia.co.nz/security-industry/feb-2018-state-industry/ (accessed 07 September 2019).

44 Andrew Thorburn, "INTERVIEW: State of the industry with Andrew Thorburn", New Zealand Security Magazine, December 2017 - January 2018. Available at http://www.defsecmedia.co.nz/security-industry/ (accessed 07 September 2019).

45 The three NZQA unit standards that comprise mandatory training include: 27360 - Conflict Management (Theory), 27361 - Conflict Management (Practical), and 27364 - Introduction to the Security Industry.

46 Keith Newman, "Getting security industry training on track", New Zealand Security Magazine, April - May 2017. Available at http://defsecmedia.co.nz/security-industry/april-2017-getting-training-ontrack/ (accessed 07 September 2019).

47 The ASIS International Board Certifications include the PSP (Physical Security Professional), APP (Associate Protection Professional), CPP (Certified Protection Professional) and PCI (Professional Cerfitied Investigator).

48 Bradley, loc cit. p. 164.

49 Keith Newman, "NZ's security industry slammed for failure to train", New Zealand Security Magazine, February - March 2017. See 2016 Report of External Evaluation and Review of The Skills Organisation. Available at http://defsecmedia.co.nz/security-industry/nzsecurity-feb2017-training/ (accessed 07 September 2019).

50 Thorburn, interview.

51 Anthony Bergin, Donald Williams and Christopher Dixon, op cit. p.18.

52 Morrison, interview.

53 Doug Martin and Simon Mount QC, Inquiry into the use of external security consultants by Government agencies, 18 December 2018, State Services Commission, New Zealand Government, p. 49. Available at http://www.ssc.govt.nz/assets/Legacy/resources/Report-of-the-inquiry-into-the-use-of-external-security-consultants-by-government-agencies.pdf (accessed 07 September 2019).

54 The only historical example of formal ongoing police-industry engagement is the now-defunct Crime Prevention Partnership Forum (CPPF). See "Police, Business sign up to Crime Prevention Forum", Scoop.co.nz, New Zealand Police Press Release, 04 June 2010. Available at http://www.scoop. co.nz/stories/BU1006/S00122/police-business-sign-up-to-crime-prevention-forum.htm?from-mobile=bottom-link-01 (accessed 07 September 2019).

55 "NZ among the least corrupt public sectors in the world", Transparency International Press Release, 29 January 2019. Available at http://www.scoop.co.nz/stories/PO1901/S00148/nz-among-theleast-corrupt-public-sectors-in-the-world.htm (accessed 07 September 2019).

56 New Zealand Defence Force Annual Report for the year ended 30 June 2014, Headquarters New Zealand Defence Force, New Zealand Government, p.31. Available at http://www.nzdf.mil.nz/downloads/pdf/public-docs/2014/nzdf-annual-report-30june2014.pdf (accessed 07 September 2019). 
57 “Citizens' Satisfaction Survey: Summary of Key Results for 2017-18”, Gravitas. Available at https:// www.police.govt.nz/sites/default/files/publications/citizen-satisfaction-survey-infographic-2018.pdf (accessed 07 September 2019).

58 Michael Pepper, "Interview Series: State of the Industry," New Zealand Security Magazine, Oct/Nov 2017. Available at http://www.defsecmedia.co.nz/security-industry/oct-2017-state-industry/ (accessed 12 September 2019).

59 Thorburn, interview.

60 Charmaine S Hayes-Jonkers, Bouncers, Brutes and Brawn: Are bouncers being discriminated against in news reports? A critical discourse analysis, $\mathrm{PhD}$ dissertation, James Cook University, 2015. Available at https://researchonline.jcu.edu.au/43775/1/43775-hayes-jonkers-2015-thesis.pdf (accessed 07 September 2019).

61 Wadds, Phillip, “Crime, Policing and (In)Security: Press Depictions of Sydney's Night-Time Economy", Current Issues in Criminal Justice, 13; (2015) 27(1) 95. In June, Australian media reports unnecessarily conflated the Australian Football League's (AFL) controversial deployment of 'behaviour awareness officers' at AFL venues in Melbourne with the suspension of around 400 guards working across the Victoria over allegations of security license fraud. Such reportage shifted the focus of criticism away from the unpopularity of the AFL's security deployment decision and onto the professionalism of the security industry itself.

62 Bergin, et al., op cit. p.5.

63 Bradley, loc cit.. p.166.

64 Nicole Lawton, "Rogue security guard fined \$18,000 for unlicensed security work in Auckland", Stuff.co.nz, 23 April 2019. Available at https://www.stuff.co.nz/business/112222129/rogue-securityguard-fined-18000-for-unlicensed-security-work-in-auckland (accessed 07 September 2019).

65 Thorburn, interview.

66 Achievement of NZSA accredited member status involves a five-yearly audit against Codes of Practice prepared by the NZSA that recognise and represent existing standards and industry best practice. See https://security.org.nz/about-nzsa/auditing/ (accessed 08 September 2019). 